\title{
A Benchmarking of Major Seaports of India
}

\author{
Sandip Solanki, Krishna Murthy Inumula
}

\begin{abstract}
This research study uses annual time series data 1999-2017 on selected physical performance indicators vessel traffic, average pre-berthing waiting time, average turn round time (ATRT), percentage of idle time at berth to time at working berth (PIBTW) and average output per ship berth day (AOPBD) of major ports in India. These selected physical performance indicators analysed by the method of principal component factor analysis which had given equal weights to the indicators thereby ranked the ports based on the overall score. Result found that JNPT port occupies the first position with a total score of 966 awarded rank 1, followed by Ennore port second rank with a score of 789 and Kandla port occupying with rank three with a total score of 712, Kolkata, Haldia and Tuticorin ports showed poor performance and are ranked 13, 12 and $11^{\text {th }}$ positions respectively.
\end{abstract}

Key Words: Port Ranking, Physical Performance Indicator, Benchmarking and Factor Analysis

JEL Code: F14, L92, P17

\section{INTRODUCTION:}

India has a rich history of internal and external trade through ports. Indian ports play a significant role in transforming Indian economy to a new level at par with the developed economy. The majority of industries in India \& around the world are located in the coastal belts, in the vicinity of major ports. India handled the tune of 561.39 MT cargo during April -January 2018 and currently 578.86 MT of cargo during April-January 2019, through its 13 major ports, representing a growth of 3.11 per cent. In the era of the globalization, Indian ports saw a good competition among the neighbouring ports that helped more efficient import and export business contributing to national development in creating new import and export zones in the country. As seaports handle the majority of international merchandise trade, ports act as a hub for the shipping of goods between the nations and existence of developed ports help in the movement of inbound and outbound cargo between trading nations. Geographic concentrations of ports occur in all major trading regions and their solidity is strictly connected to the economic well-being of their neighbourhoods and the foreign provinces where they are connected by shipping services (Pettit \& Beresford, 2008). An efficient seaport infrastructure provides comparative advantages to the nation in the global market. Therefore, the systematic appraisal of seaport efficiency can reveal their relative positions in the competitive environment. The paper has been organized into five sections. The first section gives an introduction and provides some necessary information about the background of the study. The second section assesses the literature.

Revised Manuscript Received on March 2, 2020.

*Correspondence Author

Dr. Sandip Solanki*, Symbiosis Institute of International Business (SIIB), Symbiosis International (Deemed University), Pune, Maharashtra, India. Email: sandip.solanki@ siib.ac.in

Dr. Krishna Murthy Inumula, Symbiosis Institute of International Business (SIIB), Symbiosis International (Deemed University), Pune, Maharashtra, India. Email: dr.krishna@siib.ac.in
Data sources and methodology have been presented in the third session. The results have been described in the fourth section. The final and fifth section concludes with conclusions and some policy implications of the study.

\section{LITERATURE REVIEW:}

There is no study on physical performance indicators covering the time series 1999-2017 with particular reference to India. Some literature reviewed as below;

Jose L. Tongzon \& Ganesalingam (1994) compared the performance and efficiency of the ASEAN ports by their (similar) external foils. The results inveterated that the ASEAN ports have realized advanced stages of competence in the use of cranes, berths and storage areas, with the Singapore port being the highest player. However, they are usually less effective in terms of appropriateness, labor, and use of tugs. The rates in ASEAN ports are also significantly more than those of their (similar) foreign counterparts. Rajasekar, Ashraf, \& Deo (2014) highlighted that JNPT seaport rated the excellent competent port amongst designated key ports in India. Jim Wu \& Lin (2008) found that the efficacy worth of the vessel seaport in India is second only to the US port of Los Angeles among the ports surveyed in the developed countries. Prabir De (2002) studied further growth in the seaport is highly dependent on how quickly new machinery and better facilities can accommodate it. Coto-Millan, Banos-Pino, \& RodriguezAlvarez (2000) analysed annual data for the 27 Spanish ports from 1985 to 1989 , highlighted that comparatively bigger seaports are economically additional incompetent. De (2006) reviewed that ports in India are becoming more wealth concentrated in the post reform period, and except one, the rest of all Indian ports showed statistically substantial variations in TFP's overall productivity factor in the last quarter of a century. The study also found that, contrary to popular belief, the post-reform economic climate still has no significant influence on the routine of Indian ports in terms of the most popular performance degree, the TFP.

Jose Tongzon, (2001) used Data Envelopment Analysis (DEA) to provide competence measurements for four Australian and twelve other global vessel ports. Research has shown that the ports of Melbourne, Rotterdam, Yokohama and Osaka are the greatest incompetent ports, based on continuous and adjustable returns to scale norms, largely due to the massive loose in their vessel berths. J. Wu, Yan, \& Liu (2010) results indicated that the number of berths and the capital deployed are the most sensitive measures impacting performance of most container ports. 


\section{A Benchmarking of Major Seaports of India}

The study analysed 77 global container ports. Cuadrado, Frasquet, \& Cervera (2004) found that the selection of a port made by clients-freight companies and export and import companies-is not based solely on location; the different port services offered and the quality of service are highly relevant. Woo, Pettit, \& Beresford (2011) presented that seaport productivity is multilayered, it is not just restricted to inside procedures, but also connected to external facility features such as facility superiority, etc.

Cheon (2007) examined that port efficiency is formed not only by the strength of interplanetary rivalry, but also by the aptitude of port specialists to device groundbreaking official practices in the context of a internationalized, modest world trade arrangement.

Valentine \& Gray (2001) studied that the simple structure is the most efficient form of organizational structure, whilst ownership structure does not appear to have any significant influences upon efficiency. Organizational restructuring of an inefficient port must not been seen in its own right to be the panacea, but must go hand-in-hand with new financing and investment. Pantouvakis \& Dimas (2010) found that ISO-certified seaports are financially extra competent than their non-certified players. De \& Ghosh (2003) found that the fundamental affiliation amongst port result and port traffic flow using Indian data. The use of the co-integration investigation resulted in performance being preceded by traffic in most ports in India. Estrada, Jenatabadi, \& Chin (2017) found that the marginal level of seaport efficiency is centered on how the human capital factor can be adapted to these new changes. Park \& De (2014) found that alternate DEA is a possibly prevailing method to the assessment of the general competence of ports. Atul Deshmukh (2002) found that only the JNPT seaport has exposed some optimistic competence related to other key seaports in India. Prakash Gaur, Shivani Pundir, \& Tarun Sharma (2010) tried to probe on how ports in developing countries like India should increase their capacity from operative size to likely size and to complete size. The study found that if Indian seaports grow at a very high development speed, they may face size limitations. It means adding capacity without improving the efficiency of the system would result in underutilizing the potential capacity of the system. The study suggested that institutional cooperation could be used as a strategic tool to improve efficiency and, at the same time, options such as public private participation should be tested by the government to improve competition and, subsequently, the efficiency of ports.

Dwarakish \& Salim (2015) studied the role played by ports in the development of a nation. Gaur et al., (2011) argued that, although major programs and actions are launched to upsurge the size of seaports, there is a lack of immediate need to increase the efficiency of port operations. J. Wu, Yan, \& Liu (2009) extended the Doyle and Green model by considering the DMU groups to determine the final cross-efficiency. A new approach based on the crossefficiency assessment method is being developed and applied to the efficiency analysis of 28 container ports in 12 Asian countries. Feng, Mangan, \& Lalwani (2012) suggested that Western European seaports has to develop administration provision, decrease seaport rates, spread seaport possession and advance seaport connectivity, while Eastern Asian seaports require to advance levies facilities, increase vicinity facilities, upsurge logistic demand, inspire intermodals and set up' dry ports.' SangHyun Cheon (2007) observed that ports across the world have improved in their productivity due to three main reasons. These three are: (a) improvement in management in capital inputs, (b) production scale adjustments, and (c) technological progress. The study also found that large-scale ports need to be more efficient, as they have adopted in the abovementioned points. The study also notes that port efficiencies also depend on the ability of port establishments to device ground-breaking formal practices in a global competitive environment. KM Chudasama (2009) presented that the physical facilities of ports make a significant contribution to the largely result of the seaport. The size of freight held, one of the functioning factors, meaningfully affected the outcome of seaport.

\section{DATA \& METHODS}

\section{A. Data and Scope}

This research study uses annual time series data 1999 2017 on selected physical performance indicators vessel traffic, average pre-berthing waiting time, normal turn round period, proportion of indolent period at berth to time at working berth and average productivity per ship berth daytime of major Indian seaports. The data is extracted from Indiasta.com web portal from the source of Ministry of Shipping, Road Transport \& Highways Government of India. The expansion of the seaport segment is significant for the growth of sea trade in existing globalized world. In the first four decades of post-independence, India's shipment and seaport segment saw intense development on the inventiveness of deliberate progress and lively administration provision. Over two thirds of seaport shipment handling capacity and more than half of India's national transport weight have been recognized in the first four periods of freedom.

India lacks of inter-port and intra-port competition that has led to significant increases in productivity in other countries due to unfortunate interior connectivity and a rule management that protects local seaports from economic weights. In this context, the present study identifies five physical performance indicators on the basis of which the major ports of India are benchmarked by giving them ranks based on the best performance.

\section{B. Research Methods}

Descriptive research design is used in this study, simple arithmetic measures like descriptive statistics mean and standard deviation describe the average values of data variables and their deviation from the average value. The compounded annual growth rate (CAGR) is a useful measure of growth over the study period it gives the growth rate of physical indicators over the period of time. 
Correlation matrix is used to measure the linear relationship between physical performance indicators of major ports, the correlation coefficient $(r)$ value determines the magnitude and direction of correlation, if the value of $r$ lies between 0.75 and 1 expect high optimistic association, between 0.5 and 0.75 modest optimistic association and 0 to 0.5 low positive correlation. If the value of $r$ lies between -1 and -0.75 expect high negative correlation, between -0.75 and -0.5 moderate adverse association and -0.5 to 0 low negative correlation.

A comprehensive study by Nardo, M.,et al. (2005). Tools for Composite Indicators Building used in this study as a reference. Principal component based factor analysis to weigh the performance indicators in port ranking, the detail methodology is as follows. Principal component analysis (PCA) based factor analysis is a method of data reduction technique in which the number of factors extracted are lesser than the variables in such a way that the first factor represent highest likely difference followed by the next highest and so on such that all likely difference in the variables or pointers represented by the least likely quantity of factors. After verifying the correlation structure of the variables the next step is to determine the number of factors to be selected based on value of Eigen value or higher proportion of explained variance methods. The standard practice is to choose factors that: (i) have associated eigenvalues larger than one; (ii) cumulatively contribute to the explanation of the overall variance by more than $60 \%$. The next step is to rotate the factors (usually varimax method of rotation) so that the variance extracted will be distributed proportionately to the selected factors. The final step concerns the structure of the mass of the background of the factor loadings after rotation, given that the square of the factor loadings represents the percentage of the total unit alteration of the pointer clarified by the aspect. The approach taken by Nicoletti G., Scarpetta S., Boylaud O. (2000) is the grouping of sub-indicators with the highest loading factors in the composite indicator.

The factor weights are obtained by dividing the square of the factor loadings by the explained variance of that factor (Eigen value), the proportion of factor variance is obtained by dividing the explained variance by the total variance. The final weights are obtained as a sum product of proportion of factor variance and factor weights. The original variables are transformed in to standardized variables by a suitable transformation then multiplied with the final weights as a sum product to get the total score for each decision making unit (in this study the major ports of India) higher the total score better the rank in terms of physical performance indicators.

\section{RESULTS \& DISCUSSIONS}

\section{Trend of Data Variables}

\begin{tabular}{|c|c|c|c|c|c|c|c|c|c|c|c|c|c|c|c|c|c|c|c|}
\hline \begin{tabular}{|l|l} 
PORT \\
\end{tabular} & $\mid 1999-0012$ & $00-01$ & $001-02.2$ & $2002 \cdot 13$ & $2003 \cdot-14$ & $2004-15$ & 2005.0162 & $2006-07$ & $2007 \cdot 08$ & $2008-19$ & $2009-102$ & 2011 & $2011 \cdot 12$ & $2012 \cdot 1.2$ & $013 \cdot 14$ & 4152 & 5.162 & $177 \mathrm{~A}$ & AVG \\
\hline Kolkitata & 922 & 687 & 644 & 677 & 687 & 730 & 734 & 891 & 1002 & 1057 & 1301 & 1301 & 1203 & 1226 & 1244 & 1334 & 1442 & 1336 & 1020 \\
\hline Hadilin & 1258 & 1405 & 1529 & 1659 & 1832 & 2006 & 2328 & 2300 & 2335 & 2399 & 2166 & 2189 & 1982 & 1943 & 1970 & 1907 & 2026 & 2088 & 1998 \\
\hline \begin{tabular}{|l|} 
Paradip \\
\end{tabular} & 712 & 886 & 890 & 887 & 961 & 1053 & 1187 & 1355 & 1513 & 1536 & 1531 & 1487 & 1328 & 81274 & 1443 & 1400 & 1521 & 1500 & 1252 \\
\hline Viedthanatam & 1654 & 1648 & 1500 & 1622 & 1677 & 18055 & 2071 & 2052 & 2346 & 2347 & 2466 & 2459 & 2432 & 2. 2041 & 1970 & 1992 & 2018 & 1944 & 2001 \\
\hline Emoner & & & 71 & 154 & 166 & 171 & 173 & 201 & 213 & 250 & 273 & 293 & 385 & \begin{tabular}{|l|l|}
5 & 475 \\
\end{tabular} & 689 & 779 & 813 & 8021 & 360 \\
\hline Chemail & 179 & 1775 & 1598 & 1593 & 1656 & 1669 & 1857 & 2559 & 2025 & 2078 & 2132 & 2881 & 2013 & \begin{tabular}{|l|l|}
3 & 1928 \\
\end{tabular} & 1004 & 1790 & 1733 & 1600 & 1852 \\
\hline Triboin & 1071 & 1205 & 1400 & 1426 & 1479 & 1435 & 1558 & 1509 & 1576 & 1524 & 4) 1444 & 1402 & 1376 & $6 \mid 1222$ & 1095 & 1380 & 1588 & 1662 & 140 \\
\hline Coctin & 973 & 969 & 979 & 945 & 912 & 821 & 959 & 907 & 806 & 757 & 872 & 819 & 833 & \begin{tabular}{|l|l|}
3 & 875 \\
\end{tabular} & 995 & 997 & 1169 & 12216 & 934 \\
\hline Mangable & 749 & 734 & 763 & 832 & 876 & 1057 & 1000 & 1015 & 1114 & 1184 & \begin{tabular}{|l|l|}
4186 & \\
\end{tabular} & 1097 & 1136 & \begin{tabular}{|l|l|}
6 & 1072 \\
\end{tabular} & $\begin{array}{lll}1062 \\
\end{array}$ & 1032 & 1243 & \begin{tabular}{|l|l|}
1447 & \\
\end{tabular} & 1038 \\
\hline Momingalo & 505 & 559 & 597 & 626 & 677 & 664 & 642 & 699 & 748 & 805 & 5 & 853 & 785 & 475 & 398 & 519 & 605 & 7600 & 656 \\
\hline IN.P.T & 1338 & 1654 & 1883 & 17766 & 20105 & 2064 & 2335 & 2775 & 3119 & 2881 & 1. 3049 & 3100 & 2929 & (29) 2558 & 2526 & 2662 & 2780 & 2720 & 2456 \\
\hline Miumbai & 2233 & 1921 & 1776 & 1629 & 1800 & 1883 & 2053 & 2087 & 20066 & 19331 & 2006 & 2002 & 2017 & \begin{tabular}{|l|l|}
1908 \\
17
\end{tabular} & 2626 & 1959 & 2037 & 1994 & 1998 \\
\hline Kandla & 1855 & 1452 & 1672 & 1813 & 1823 & 1940 & 2124 & 2318 & 2558 & 2517 & 2776 & 2692 & 2714 & 42764 & 2304 & 2216 & 2513 & 2558 & 2259 \\
\hline TOTAI & 15667 & $\mid 18805$ & $15+12$ & 15629 & 16651 & 1378 & 19171 & 201689 & 21526 & $21366]$ & 620207 & 21975 & 21163 & 10056 & 10750 & $\mid 9877$ & |4880 & 1655 & \\
\hline
\end{tabular}

Figure 1 Vessel Traffic at Major Ports (1999-2017)

Vessel Traffic (VT): one of the port throughput measures represents the number of vessels sailed over time mostly affected by the demand for cargo, cargo volumes and physical capacity of the port. The traffic in terms of the number of vessels (excluding container) handled by the major ports considered in the study (Figure 1) have increased from 15067 to 21655 during the period 1999-00 to 2016-17 registering a compound growth rate of $2.24 \%$. The major ports of India experienced consistently increasing trend in vessels traffic throughout the period.

The JNPT tops the list with highest vessels traffic increased from 1338 in 1999-00 to 2720 in 2016-17, with an average container vessels traffic of 2467 with average growth rate of $12.73 \%$ during the study period, followed by Kandla Port Trust whose average vessels traffic during the period was 2259 with an average growth rate of $11.72 \%$, Visakhapatnam port occupies third place with an average vessels traffic 2001 with an typical progression degree of $10.44 \%$. The lowest number of vessels traded was at Ennore Port with an average vessels traffic of 369 with an average growth rate of $1.82 \%$.

\begin{tabular}{|c|c|c|c|c|c|c|c|c|c|c|c|c|c|c|c|c|c|c|c|}
\hline WLITI & 5000 & 1300 & 1885 & 1335 & I3Y & $\pi / 3$ & IJT] & Jit58 & 1884t & 18870 & SESSt & \begin{tabular}{|l|} 
587J \\
\end{tabular} & SHed & 5012 & 78se & 5080 & 1880 & \begin{tabular}{|l|} 
Tाग \\
\end{tabular} & \\
\hline Ysing & & Гथा & 350 & 580 & 500t & IIJt & It & 588 & Set & Ses & 500 & 335 & $3 \mathrm{Jt}$ & 328 & SIS & 525 & T.88 & 505 & \\
\hline ] & & ISPe & 158 & TII & O185 & 08. & I" & & 020 & I'HI & ITR & 13 & 3 & Tes & ТT8 & 80 & iss & tie & JT \\
\hline I'T'L' & 0 & d'es & 0285 & 0 070 & DOES & O'IS & 08 & & 083 & 028 & 028 & Г2] & T'T3 & II3I & T08 & 800 & ITJ & 0"3s & 088 \\
\hline ypumbinaso & It & 535 & IJt & Тबנ & 528 & \begin{tabular}{|l|l|}
533 \\
\end{tabular} & SII & 523 & 5IT & נענ & 3te & tos & sodt & \begin{tabular}{|l|} 
Tes \\
\end{tabular} & It's & I'II & [.38 & Ies & IN \\
\hline 7roviantis & I" & o's & oye & ode? & 022 & \begin{tabular}{|l|} 
D'd \\
\end{tabular} & \begin{tabular}{|l|l|} 
\\
\end{tabular} & OPt & DPB & owe & OBI & 028 & 0 & IIt & O881 & 000 & Je & oes & Ollt \\
\hline Cocosidy & 08 & old & 022 & Dits & $0+3$ & ote & {$[2]$} & 028 & DOO & 030 & OBP & I03 & ITR & I & 023 & $08 \mathrm{t}$ & dee & 0’8 & 015 \\
\hline Inty & 300 & $T+0$ & 528 & I 33 & 0 & \begin{tabular}{|l|} 
\\
\end{tabular} & 013 & ISt & IISt & T100 & ITP & 158 & ז'बा & T3T & एT. & Tos & 533 & 18 & $\mathrm{T3t}$ \\
\hline 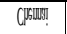 & 580 & st? & Ije & TT3 & 558 & 023 & Deer & 028 & I"2 & 530 & 532 & I'EI & I'Te & 080 & OAII & OAI & ONt & 038 & JSt \\
\hline Eiluolis & & & o's & 008 & oos & 000 & 078 & 073 & 030 & \begin{tabular}{|l|l|}
053 \\
\end{tabular} & 031 & OPe? & O'JP & TI33 & 538 & 52I & $f 13$ & \begin{tabular}{|l|l|} 
O3P \\
\end{tabular} & 0.2 \\
\hline 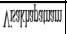 & It0 & 0132 & 013 & OगI & O'Se & \begin{tabular}{|l|l|} 
o's \\
\end{tabular} & IV3 & 083 & ITO & 158 & 120 & 585 & $58 \mathrm{t}$ & 520 & $18 \mathrm{~d}$ & 528 & I'ds & iJs & Thd \\
\hline brughb & ITO & I'A] & Tाס & 085 & Olit & \begin{tabular}{|l|l|}
12 \\
\end{tabular} & Iiot & I'R & 583 & 535 & 830 & 200t & 300 & Ire? & Tot & fII & 502 & 5its & SSP \\
\hline  & TPO & वग & OगI & 081 & oas & \begin{tabular}{|l|l|} 
II3 \\
\end{tabular} & \begin{tabular}{|l|}
572 \\
\end{tabular} & I'25 & 580 & 3398 & $\$ 30$ & 313 & $52 \mathrm{t}$ & 558 & S5T & IT3 & opep & 550 & $50 \mathrm{H}$ \\
\hline Yorysy & 500 & Def & 028 & 025 & 025 & $\mid$\begin{tabular}{l|l|}
$0+0$ \\
\end{tabular} & oto & ot3 & 028 & ope & TII & $4 \sqrt{33}$ & o's & \begin{tabular}{|l|} 
DET \\
\end{tabular} & \begin{tabular}{|l|l}
022 \\
\end{tabular} & \begin{tabular}{|l|l} 
OII \\
\end{tabular} & 020 & \begin{tabular}{|l|l|}
023 \\
\end{tabular} & $O x$ \\
\hline
\end{tabular}

Average Pre-berthing Waiting time (APBT): Time taken by a vessel from entrance at the dock to the reporting post till it arrives at the operational berth excluding time taken for internal movement, obtained by dividing the total pre-berthing waiting time of all freight containers cruised from the seaport through a period by the number of freight containers navigated during that period. 


\section{A Benchmarking of Major Seaports of India}

Results show that (Figure 2) Kandla port registered highest average pre-berthing time of 2.58 days with average growth rate of $15.67 \%$, followed by Paradip Port which registered 2.26 days with an average growth rate of $11.89 \%$ and Mormugao port of 2.11 days with average growth rate of $10.87 \%$. Kolkata had the lowest average pre-berthing time of 0.66 days, followed by Cochin with 0.72 days, Mangalore with 0.74 days.

\begin{tabular}{|c|c|c|c|c|c|c|c|c|c|c|c|c|c|c|c|c|c|c|c|}
\hline ORI' & & & & 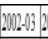 & 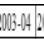 & $w$ & 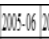 & 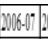 & $2007 \cdot-18] 2$. & 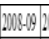 & 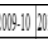 & W11]. & 0.112. & . & . & $1+12$ & . & & \\
\hline & & & & 4,49 & 423 & 417 & 4212 & 436 & 5.6 & 5.10 & 680 & 621 & 5,15 & 472 & 45: & 497 & 4,78 & 4,6 & $5 . / 3$ \\
\hline & & 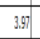 & 400. &  & 288 & 40:5 & 48: & 385 & 486 & $42:$ & 5001 & 4.5 & 352 & $395:$ & $3 \pi$ & 336 & 3.27 & 5.6 & \\
\hline ant & & 4.16 & 3.99 & 3000 & 3,16 & 34: & 355 & 354 & 5.54 & 480 & 904 & 7.17 & 6.33 & 4,35 & 46. & $700:$ & 450. & 499 & 488 \\
\hline 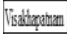 & & $37:$ & $35:$ & 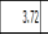 & 3.33 & 32.20 & 378 & 355 & 3.1. & 3.98 & 478 & 584 & 558 & 5.39 & 473 & 567 & 3.84 & 28.7 & 4 \\
\hline re & & & 3.62 & 222 & 198 & 172 & 222 & 188 & 208 & 2.5 & 211 & 288 & 2.17 & 295 & 434 & 432 & 6.8 & 268 & 28 \\
\hline $\min$ & 6,40 & 5.83 & 5.26 & 366 & 46: & 394 & 332 & 335 & 4.55 & 4.15 & 4.04 & 436 & 391 & 3.24 & 245 & 254 & 253 & $25:$ & 395 \\
\hline & 68. & 400 & 4.11 & 359 & 259 & 265 & 288 & 35 & 3.65 & 364 & 390 & 400 & 4,94 & 43: & 392 & 337 & + & & 3. \\
\hline ant & 320 & 311 & 2.75 & 266 & 215 & 262 & $2 \pi$ & 211 & 1.4 & 2.44 & 2008 & 220 & 128 & 158 & 176 & 169 & 218 & 1.99 & 22 \\
\hline ryjke & 3800 & 2.89 & 2.73 & 1.90 & 255 & 298 & 300 & 314 & 32. & 300 & 306 & $2 \pi 0$ & 2.55 & 3.2 & 318 & 266 & 253 & 235 & 288 \\
\hline $\operatorname{mg} x$ & 430 & 4.6. & 465 & 37 & 4.5. & 5665 & 6005 & 6.15 & 6.24 & 5,55 & 89: & 1043 & 788 & 50.08 & 450. & 397 & 3.35 & $3,6]$ & 54 \\
\hline P. & 210 & 22. & 2.98 & 1.22 & 1.73 & 1.44 & 197 & 14. & 100 & 190 & 201 & 258 & 1.94 & 2.8 & 268 & 224 & 23: & 1.96 & 2110 \\
\hline tha & 560 & 5.20 & 5.4 & 5.66 & 4.00 & $4,2$. & 4,058 & $45:$ & 40 & 4.5 & 465: & 456 & 5.22 & 558 & 45: & 409 & 3.6 & 268 & 45. \\
\hline & 62 & 432 & 6.55 & 5.9 & 5.66 & $4 \quad 462$ & $43:$ & 5,6 & 2.18 & 7.6 & 503 & 590 & 6,42 & 633 & 566 & 490 & 4.86 & 45: & 5 \\
\hline & 58500 & $49.65]$ & 54,33 & 4.9. & 4 & 5.16 & 4692 & 47,32 & 52.24 & 5336 & 61.38 & 6420 & 5813 & 5327 & 4986 & 59? & 47.3 & 1 & \\
\hline
\end{tabular}

Figure 3 Average Turn Round Time at Major Ports (1999-2017)

Average Turn Round Time (ATAT): Total period consumed by a ship at the seaport from its influx at reporting place till its exit from the reporting place, includes pre-berthing waiting time, steering time stay at working and non-working berths and shifting time.

Mormugao Seaport has the maximum (Figure 3) usual change time of 5.49 days with average growth rate of $10.59 \%$ during the study period, it was followed by Kandla port of 5.46 days with regular growth rate of $10.72 \%$ Kolkata port of 5.03 days with regular growth rate of $9.81 \%$, while the lowest turnaround time was registered at JNPT Port with 2.10 days followed by Cochin with 2.26 days and Mangalore 2.87 days.

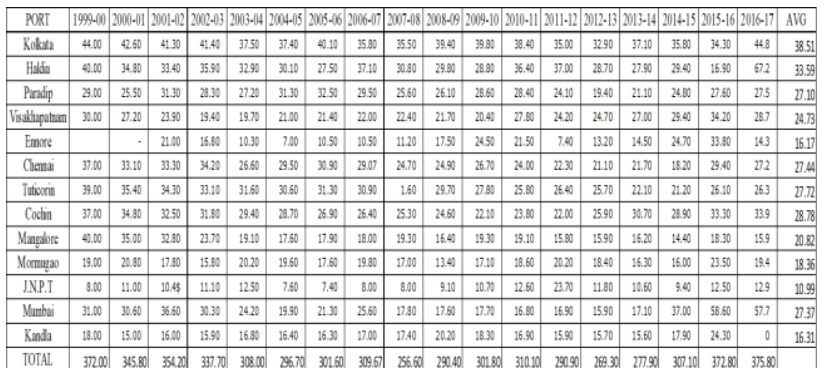

\section{Figure 4 Percentage of Idle Time at Berth of Major} Ports (1999-2017)

Percentage of Idle Time at Berth to Time at Working Berth: This is the amount of time a vessel remains idle at berth, lower idle time would ease cargo handling smoother and readiness for more vessels.

Over the study period 1999-2017 Kolkata has the highest (Figure 4) idle time at berth of 38.51 days with an typical growth rate of $12.28 \%$, followed by Haldia port of 33.59 days with an average growth rate of $10.65 \%$, Cochin port of 28.78 days with an average growth rate of $9.12 \%$. The lowest idle time at berth reported at JNPT port with 10.99 days with an regular annual growth rate of $3.55 \%$.

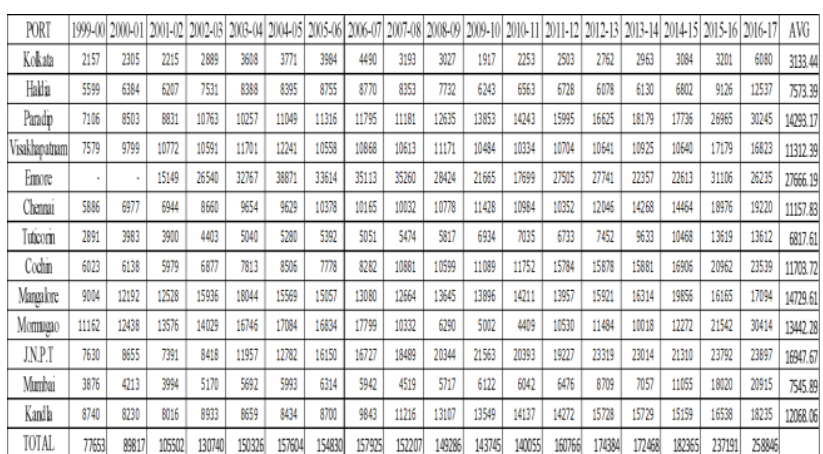

Figure 5 Average Output per Ship Berth Day at Major Ports (1999-2017)

Average Output per Ship Berth Day (AOSD): It is the total capacity held dispersed over the total number of berth days. Average output per ship held by the major ports considered in the study have increased from 77653 tons to 258846 tons during the period 1999-00 to 2016-17 registering a compound annual growth rate of $4.84 \%$.

The Ennore port tops the list (Figure 5) with highest average output per ship at 27666 tons with an regular yearly growth rate of $17.29 \%$ during the study retro, followed by JNPT Port whose average output per ship was 16948 tons with an average growth rate of $10.83 \%$, Mangalore port occupies third place with an average output per ship was 14730 tons with an average growth rate of $9.89 \%$. The lowest average output per ship traded was at Kolkata Port with an average productivity per vessel berth day of 3133 tons with a usual progression rate of $2.07 \%$.

\section{Descriptive Statistics \& Correlation Matrix}

\begin{tabular}{|l|l|l|}
\hline Indicator & Mean & Std. Deviation \\
\hline VT & 1477.77 & 655.65 \\
\hline APBT & 1.40 & 0.64 \\
\hline ATAT & 3.99 & 1.17 \\
\hline IDLETIME & 24.48 & 7.64 \\
\hline AOSD & 12257.66 & 6061.29 \\
\hline
\end{tabular}

Over the study period the major ports of India witnessed on an average vessel traffic 1477, average pre berthing waiting time 1.4 days, average turn round time was 3.99 days, average ratio of idle period at berth was 24.48 days and average output per ship berth day was 12257 tons. Out of all the five physical indicators variations in average output per ship are higher followed by vessel traffic.

\begin{tabular}{|c|c|c|c|c|c|c|}
\hline \multicolumn{2}{|c|}{ Indicator } & VT & $\begin{array}{c}\mathrm{APB} \\
\mathrm{T}\end{array}$ & $\begin{array}{c}\text { ATA } \\
\text { T }\end{array}$ & $\begin{array}{l}\text { IDLETIM } \\
\text { E }\end{array}$ & $\begin{array}{c}\text { AOS } \\
\text { D }\end{array}$ \\
\hline \multirow{5}{*}{$\begin{array}{c}\text { Correlatio } \\
\mathrm{n}\end{array}$} & VT & 1 & 0.277 & 0.039 & -0.101 & $0 . \overline{296}$ \\
\hline & APBT & $\begin{array}{c}0.27 \\
7 \\
\end{array}$ & 1 & $\begin{array}{c}0.685 \\
* \\
\end{array}$ & -0.129 & $\begin{array}{c}- \\
0.087 \\
\end{array}$ \\
\hline & ATAT & $\begin{array}{c}0.03 \\
9\end{array}$ & 0.685 & 1 & 0.262 & $\begin{array}{c}- \\
0.465\end{array}$ \\
\hline & $\begin{array}{c}\text { IDLETIM } \\
\text { E }\end{array}$ & $\begin{array}{c}- \\
0.10 \\
1\end{array}$ & $\begin{array}{c}- \\
0.129\end{array}$ & 0.262 & 1 & $\begin{array}{c}0.762 \\
*\end{array}$ \\
\hline & AOSD & $\begin{array}{c}- \\
0.29 \\
6\end{array}$ & $\begin{array}{c}- \\
0.087\end{array}$ & $\begin{array}{c}- \\
0.465\end{array}$ & -0.762 & 1 \\
\hline
\end{tabular}


The above correlation matrix shows how the physical indicators are correlated with each other, there exists a low positive correlation between vessel traffic vs pre berthing waiting time and turn round time, a low negative correlation exists between vessel traffic vs idle time at berth and output per ship berth day. Though not significant, turn round time and idle time at berth are having low positive correlation between them. Pre berthing waiting time and turn round time are moderately positively correlated and the correlation value is significant. There exists a significant negative correlation between idle time and output per ship birth day as the idle time at berth decreases the more the output per ship berth day.

\section{Ranking Port performance}

\begin{tabular}{|c|c|c|}
\hline \multicolumn{3}{|c|}{ KMO and Bartlett's Test } \\
\hline \multicolumn{2}{|c|}{$\begin{array}{l}\text { Kaiser-Meyer-Olkin Measure of } \\
\text { Sampling Adequacy. }\end{array}$} & .954 \\
\hline \multirow{3}{*}{$\begin{array}{l}\text { Bartlett's } \\
\text { Test of } \\
\text { Sphericity }\end{array}$} & Approx. Chi-Square & 25559 \\
\hline & df & 10 \\
\hline & Sig. & .004 \\
\hline
\end{tabular}

Both the tests (KMO is more than 0.7 and Bartlett's significant value less than 0.05 ) confirms that factor analysis is appropriate for the current study with the five physical indicators to measure the performance of Indian major ports.

Total Variance Explained

\begin{tabular}{|c|c|c|c|c|c|c|c|c|c|}
\hline \multirow{2}{*}{ Component } & \multicolumn{3}{|c|}{ Initial Eigenvalues } & \multicolumn{3}{|c|}{ Extraction Sums of Squared Loadings } & \multicolumn{3}{|c|}{ Rotation Sums of Squared Loadings } \\
\hline & Total & $\%$ of Variance & Cumulative $\%$ & Total & $\%$ of Variance & Cumulative $\%$ & Total & $\%$ of Variance & Cumulative $\%$ \\
\hline 1 & 2.176 & 43.517 & 43.517 & 2.176 & 43.517 & 43.517 & 1.867 & 37.347 & 37.347 \\
\hline 2 & 1.503 & 30.052 & 73.569 & 1.503 & 30.052 & 73.569 & 1.698 & 33.959 & 71.306 \\
\hline 3 & 1.010 & 20.195 & 93.764 & 1.010 & 20.195 & 93.764 & 1.123 & 22.458 & 93.764 \\
\hline 4 & .217 & 4.344 & 98.107 & & & & & & \\
\hline 5 & .095 & 1.893 & 100.000 & & & & & & \\
\hline
\end{tabular}

Factor analysis using the method of principal components extracted a total of three component accounting almost $94 \%$ contribution to the study also referred to as factors out of the five physical performance indicators considered in the study. The Eigen values (variances of the principal components) of more than 1 are considered in accounting the total variance explained. The communalities are also high justifying the maximum proportion of each indicator variance that can be explained by the principal components.

\begin{tabular}{|c|c|c|c|}
\hline \multicolumn{4}{|c|}{ Rotated Component Matrixa } \\
\hline \multirow{2}{*}{} & \multicolumn{3}{|c|}{ Component } \\
\cline { 2 - 4 } & 1 & 2 & 3 \\
\hline VT & .043 & .089 & .990 \\
APBT & -.138 & .923 & .214 \\
ATAT & .338 & .896 & -.070 \\
IDLETIME & .946 & -.025 & -.153 \\
AOSD & -.915 & -.189 & -.263 \\
\hline
\end{tabular}

Extraction Method: Principal Component Analysis.

Rotation Method: Varimax with Kaiser Normalization.

The rotated component matrix (factor loadings) using varimax rotation shows the correlation between indicator and factors. The next step contracts with the building of the bulks from the contextual of feature loadings after rotation, given that the square of factor loadings represent the proportion of the total unit adjustment of the indicator which is clarified by the factor. Thus the first component explained variance is 1.867 , followed by second component 1.698 and third component explained variance is 1.123 . The proportion of factor variance is obtained by dividing the explained variance of each factor by the total variance of all factors combined, thus the proportion of factor variance by first factor is $39.83 \%$, second factor is $36.21 \%$ and third factor is $23.95 \%$.

\begin{tabular}{|c|c|c|c|c|c|}
\hline $\begin{array}{c}\text { Factor } \\
\text { Weights }\end{array}$ & & & $\begin{array}{c}\text { Proportion } \\
\text { of factor } \\
\text { variance }\end{array}$ & $\begin{array}{c}\text { Final } \\
\text { Weights }\end{array}$ \\
\hline VT & $\begin{array}{c}0.0009 \\
77\end{array}$ & $\begin{array}{c}0.0046 \\
21\end{array}$ & $\begin{array}{c}0.8724 \\
09\end{array}$ & $\begin{array}{c}0.3983101 \\
84\end{array}$ & 0.21102 \\
\hline APBT & $\begin{array}{c}0.0101 \\
76\end{array}$ & $\begin{array}{c}0.5015 \\
9\end{array}$ & $\begin{array}{c}0.0406 \\
48\end{array}$ & $\begin{array}{c}0.3621727 \\
28\end{array}$ & 0.195451 \\
\hline ATAT & $\begin{array}{c}0.0611 \\
09\end{array}$ & $\begin{array}{c}0.4724 \\
76\end{array}$ & $\begin{array}{c}0.0044 \\
09\end{array}$ & $\begin{array}{c}0.2395170 \\
88\end{array}$ & 0.196514 \\
\hline IDLETIME & $\begin{array}{c}0.4791 \\
1\end{array}$ & $\begin{array}{c}0.0003 \\
76\end{array}$ & $\begin{array}{c}0.0209 \\
43\end{array}$ & & 0.195987 \\
\hline AOSD & $\begin{array}{c}0.4486 \\
28\end{array}$ & $\begin{array}{c}0.0209 \\
36\end{array}$ & $\begin{array}{c}0.0615 \\
91\end{array}$ & & 0.201028 \\
\hline
\end{tabular}

The factor weights are obtained by dividing the square of the factor loadings by the explained variance of that factor (Eigen value), the final weights are obtained as a sum product of proportion of factor variance and factor weights. The following table gives the final weights.

The original variables are transformed in to standardized variables by a suitable transformation then multiplied with the final weights as a sum product to get the total score for each of the major ports of India, higher the total score better the rank in terms of physical performance indicators. 


\begin{tabular}{|c|c|c|c|c|c|c|c|c|c|c|c|c|c|}
\hline TANDARDIZED & $v_{T}$ & APBT & ATAT & |DLETME & AOSD & WEGGHTS & $V_{T}$ & APBT & ATAT & DEFTINE & AOSD & \begin{tabular}{|l|l|} 
TOTAL \\
\end{tabular} & \\
\hline Kolkata & 2.76 & 29 & 1.63 & 1.00 & 100 & 21 & 580.4 & 55.33 & 3259 & 20.00 & 20.0 & \begin{tabular}{|l|l|}
185.96 \\
\end{tabular} & \\
\hline Hadia & & 1.54 & 259 & 5.92 & 242 & & 111.93 & 29.23 & 5189 & 11833 & 48.34 & 359.72 & \\
\hline Pandip & 3. & 1.32 & 1.78 & 12.41 & 4.56 & & 7124 & 25.04 & 3558 & 288.11 & 91.23 & 471200 & \\
\hline 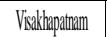 & 5.42 & 2.08 & 237 & 14.78 & 3.61 & 20 & 113.84 & 3959 & 47.46 & 25556 & 7220 & 588.65 & \\
\hline & 100 & 2.62 & 3.78 & 23.34 & 8.83 & & 2100 & 1986 & 75.55 & 466.74 & 176.59 & 789.74 & \\
\hline Chemanai & 5.02 & 234 & 2.74 & 1259 & 3.56 & & 10534 & 4.41 & 5476 & 55.86 & 71.212 & 527.59 & \\
\hline Tutronin & 3.82 & 2.24 & 2.81 & 11.79 & 2.18 & & 8021 & 4254 & 56.14 & 253.18 & $4,5,52$ & 488.19 & \\
\hline & 2.53 & 2.86 & 4.41 & 10.59 & 3.74 & & 53.10 & 54.25 & 88.11 & 211.16 & 74.70 & 481.92 & \\
\hline Mangable & 281 & 2.83 & 3.80 & 18.69 & 470 & & 59.13 & 53.85 & 75.93 & 373.78 & 94.02 & 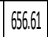 & \\
\hline Morm & 1.78 & 1.51 & 1.00 & 21.18 & 4.13 & & 37.33 & 28.67 & 2000 & 423.58 & 82.59 & 592.17 & \\
\hline J.NP.T & 6.68 & 2.66 & 4.59 & 28.39 & 5.81 & & 140.35 & 50.57 & 9171 & 567.11 & 116.14 & 966.88 & \\
\hline & 5.37 & 237 & 2.07 & 1147 & 2.48 & & 11286 & 45.02 & 41.37 & 229.49 & 49.52 & 478.25 & \\
\hline Kandla & 6.12 & 1.00 & 1.20 & 23.19 & 3.85 & & 128.49 & 19.00 & 23.98 & 453.99 & 77.03 & 71238 & \\
\hline
\end{tabular}

For the selected physical indicators of port performance JNPT port occupies the first position with a total score of 966 awarded rank 1, followed by Ennore port second rank with a score of 789 and Kandla port occupying with rank three with a total score of 712 .

For the selected physical indicators of port performance Kolkata, Haldia and Tuticorin ports showed poor performance and are ranked from last 13,12 and $11^{\text {th }}$ rank respectively. Mangalore, Mormugao and Visakhapatnam ports stood in the next best with ranks 4,5 and $6^{\text {th }}$ rank respectively.

\section{CONCLUSION}

Port performance in physical indicators reflect how efficient the port operations in terms of better cargo handling, managing time lines and efficiency of port. Both inter and intra port competition is required to assess the benchmark performance so that a healthy competition prevail between the ports. The selected physical indicators viz...vessel traffic, average pre-berthing waiting time, middling turn round time, ratio of idle period at dock to time at working dock and average productivity per vessel dock day, analysed by the method of principal component factor analysis had given equal weights to the indicators thereby ranked the ports based on the overall score. JNPT port occupies the first position with a total score of 966 awarded rank 1, followed by Ennore port second rank with a score of 789 and Kandla port occupying with rank three with a total score of 712, Kolkata, Haldia and Tuticorin ports showed poor performance and are ranked 13,12 and $11^{\text {th }}$ positions respectively.

\section{REFERENCES:}

1. Atul Deshmukh, "Indian Ports - The Current Scenario" Working Paper No. 14, Dr. Vibhoothi Shukla Unit in Urban Economics \& Regional Development, Mumbai.

2. Cheon, S. (2007). The productive efficiency of ports: lessons from the Pacific Rim Seaport's corporatization and Strategic Management: University of California at Berkeley, Institute of Urban and Regional

3. Chudasama, K. M. (2009). Performance appraisal of Indian major ports using port ranking model. IUP Journal of Infrastructure, 7(1), 7.

4. Coto-Millan, P., Banos-Pino, J., \& Rodriguez-Alvarez, A. (2000) Economic efficiency in Spanish ports: some empirical evidence. Maritime Policy \& Management, 27(2), 169-174. https://doi.org/10.1080/030888300286581

5. Cuadrado, M., Frasquet, M., \& Cervera, A. (2004). Benchmarking the port services: a customer oriented proposal. Benchmarking: an International Journal, 11(3), 320-330. https://doi.org/10.1108/14635770410538781

6. De, P. (2006). Total factor productivity growth: Indian ports in the era of globalisation. Maritime Economics \& Logistics, 8(4), 366-386.
7. De, P., \& Ghosh, B. (2003). Causality between performance and traffic: an investigation with Indian ports. Maritime Policy \& Management, $30(1)$,

$5-27$. https://doi.org/10.1080/0308883032000051603

8. Dwarakish, G. S., \& Salim, A. M. (2015). Review on the Role of Ports in the Development of a Nation. Aquatic Procedia, 4, 295-301. https://doi.org/10.1016/i.aqpro.2015.02.040

9. Estrada, M. A. R., Jenatabadi, H. S., \& Chin, A. T.H. (2017) Measuring Ports Efficiency under the Application of PEP-Model Procedia Computer Science, 104, 205-212. https://doi.org/10.1016/j.procs.2017.01.107

10. Feng, M., Mangan, J., \& Lalwani, C. (2012). Comparing por performance: Western European versus Eastern Asian ports International Journal of Physical Distribution \& Logistics Management, 42(5), https://doi.org/10.1108/09600031211246537

11. Jim Wu, Y.-C., \& Lin, C.-W. (2008). National port competitiveness: implications for India. Management Decision, 46(10), 1482-1507. https://doi.org/10.1108/00251740810920001

12. Kek Choo Chung, "Port Performance Indicators" file:///O/PUBLIC/twu_xweb/transpor/publicat/td-ps6.htm $\quad(2$ of 5)07/17/2005 10:00:22 AMKutin, N., Nguyen, T. T., \& Vallée, T. (2017). Relative Efficiencies of ASEAN Container Ports based on Data Envelopment Analysis. The Asian Journal of Shipping and Logistics, 33(2), 67-77. https://doi.org/10.1016/j.ajs1.2017.06.004

13. Langen, P. de, Nidjam, M., \& van der Horst, M. (2007). New indicators to measure port performance. Journal of Maritime Research, 4(1), 23-36.

14. Nardo, M., et al. (2005). Tools for Composite Indicators Building, EUR 21682 EN (C) European Communities, 2005 weblink: http://publications.jrc.ec.europa.eu/repository/bitstream/JRC31473/E UR\%2021682\%20EN.pdf

15. Nicoletti G., S. Scarpetta and O. Boylaud, (2000), Summary indicators of product market regulation with an extension to employment protection legislation, Economics department working papers NO. 226, ECO/WKP(99)18. http://www.oecd.org/eco/eco

16. Pantouvakis, A., \& Dimas, A. (2010). Does ISO 9000 series certification matter for the financial performance of ports? Some preliminary findings from Europe. Maritime Policy \& Management 37(5), 505-522. https://doi.org/10.1080/03088839.2010.503714

17. Park, R.-K., \& De, P. (2014). An Alternative Approach to Efficiency Measurement of Seaports. In H. E. Haralambides (Ed.), Port management (pp. 273-292). Houndmills, Basingstoke, Hampshire: Palgrave Macmillan. https://doi.org/10.1057/9781137475770_13

18. Pettit, S., \& Beresford, A. (2008). An Assessment of Long-Term United Kingdom Port Performance: A Regional Perspective. Maritime Economics \& Logistics, 10(1-2), 53-74 https://doi.org/10.1057/palgrave.mel.9100191

19. Prabir De, "Productivity, Efficiency and Technological Changes in Indian Ports" PIANC 2002, 30th International Navigation Congress, Sydney, September 2002, page 1751-1766.

20. Prakash Gaur Shivani Pundir Tarun Sharma, "Ports face inadequate capacity, efficiency and competitiveness in a developing country: Case of India" Page 1 - 33.Rajasekar, T., Ashraf, P. S., \& Deo, P. M (2014). Measurement of efficiency of major ports in India-a data envelopment analysis approach. International Journal of Environmental Sciences, 4(5), 926-936.

21. SangHyun Cheon, "The Productive Efficiency of Ports:Lessons from Pacific Rim Seaport's Corporatization and Strategic Management' Working Paper 2007-03, Institute of Urban and Regional Development, University of California at Berkeley.Tongzon, Jose. (2001). Efficiency measurement of selected Australian and other international ports using data envelopment analysis. Transportation Research Part a: Policy and Practice, 35(2), 107-122.

22. Tongzon, Jose L. (1995). Determinants of port performance and efficiency. Transportation Research Part a: Policy and Practice, 29(3), 245-252. https://doi.org/10.1016/0965-8564(94)00032-6

23. Tongzon, Jose L., \& Ganesalingam, S. (1994). An evaluation of ASEAN port performance and efficiency. Asian Economic Journal, 8(3), 317-330

24. Valentine, V. F., \& Gray, R. (Eds.) 2001. The measurement of port efficiency using data envelopment analysis. : Vol. 22: Seoul South Korea.

25. Wang, T.-F., Song, D.-W., \& Cullinane, K. (2003). Container port production efficiency: a comparative study of DEA and FDH approaches. Journal of the Eastern Asia Society for Transportation Studies, 5(10), 698-713. 
26. Woo, S.-H., Pettit, Stephen, \& Beresford, Anthony. (2011). Port evolution and performance in changing logistics environments. Maritime Economics \& Logistics, 13(3), 250-277 https://doi.org/10.1057/mel.2011.12

27. Wu, J., Yan, H., \& Liu, J. (2009). Groups in DEA based crossevaluation: An application to Asian container ports. Maritime Policy \& Management, 36(6), 545-558.

28. Wu, J., Yan, H., \& Liu, J. (2010). DEA models for identifying sensitive performance measures in container port evaluation Maritime Economics \& Lo

29. gistics, 12(3), 215-236. https://doi.org/10.1057/mel.2010.6

\section{AUTHORS PROFILE}

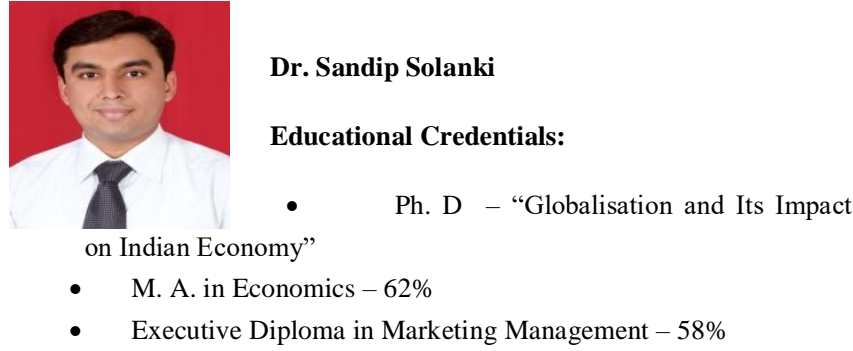

Academic Experience:

- Having more than fifteen years of teaching experience in various B-Schools as a faculty of Management. Presently working as an Associate Professor \& Head International Business Dept. @ Symbiosis Institute of International Business (SIIB), SIU, Pune.

Research Experience:

- Having more than ten years of research experience which embraces more than 35 reseach papers publication in various Scopus \& ABDC, UGC listed journals, PhD supervisor and completed research project funded by SIU.

Conducted MDP:

- $\quad$ Conducted Management Development Program for numerous MNCs like Wipro Ltd., Pune, Wipro Ltd., Chennai, Mahindra \& Mahindra Ltd., Zaheerabad, Amdocs Pune, Awaya Pune, Welspun Ltd., Mumbai, FIEO - set up by Ministry of Commerce, Government of India etc.

Board of Studies Member:

- Chairperson, Board of Study, Faculty of Management, International Business, Symbiosis International University, Pune.

Invited as a Conference Chairperson:

- Chaired many international and national conferences in India and abroad which includes Waljat College of Applied Sciences, Muscat, Oman, Nepalese Academy of Management, Kathmandu, Nepal, etc.

Invited as a Speaker:

- Under the Ishwarbhai Ambalal Fellowship Programme at S.P. University, Anand

- Export Promotion Council for Handicrafts, at Pune

- Gujarat Technological University, Gujarat

- World Education Summit 2013 for the session of 'Industry Academia Bridge: Channelizing Collaborative Models', organized by AICTE and Elets, New Delhi

- Department of Management Sciences (PUMBA), University of Pune, Pune, on March 20-21, 2009.

Associated:

- $\quad$ Life member of Indian Economic Association

- Life member of Gujarat Economic Association

- Member of the Indian Society for Labour Economics, New Delhi

- Indira Gandhi National Open University.

Personal Details:

- $\quad$ Date of Birth: $9^{\text {th }}$ September 1976

- $\quad$ Languages Known: English, Hindi \& Gujarati

- Hobbies: Music and Reading

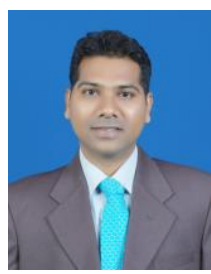

Dr. Krishna Murthy Inumula - Associate Professor P.hD (Statistics)

M.Phil (Development Statistics)

U.G.C._Net Qualified (Lectureship)

Certified in Project Management (PMA-IPMA)

Professional trainer in various fields like Market Research Analytics, Statistics, Operations Management, Project Management, Econometrics, Quality Control and Business Analytics have been constantly enriching experience through the executive education development programs like Faculty Development (FDP), Management Development (MDP) and Executive Development to promote and contribute research and innovation among knowledge community.

Some of the glimpses are, conducted as a resource person Corporate Training Program MDP in Project Management and its contemporary Applications in Evaluating the Port Performance for the Employees of Gujarat Maritime Board (GMB) -Ahmadabad, Gujarat, India. Eight corporate batches were trained span over two years 20092011. Executed MDP - Project Management for Petro Bangla to the corporate of Bangladesh Petroleum Company, Bangladesh Conducted MDP- Materials \& Operations Management for Corporate of Oil \& Gas Sector, Indian Oil Corporation Ltd. (Pipeline Division), Noida, UP, India. Chairperson for MDP in ISB\&M Pune - Small \& Medium Enterprises: Agenda for Profitability.

Professional data analyst in dealing with complex data models, expertise in various software like SPSS, MINITAB, EVIEWS and MSPROJECT. Time series data modelling, casual data analysis and multivariate data analysis are the core expertise. Authored and contributed to management topics around 31 papers and articles in various national and international journals and conferences. Some of the journals include Arthshastra: Indian Journal of Economics \& Research, NICMAR: Journal of Construction Management, Indian Journal of Finance Prabandhan: Indian Journal of Management and International Journal of Ecological Economics and Statistics. Rich experience in handling hundred plus master's level management dissertation projects and guided so far one M.Phil. and one Ph.D scholars in the areas of general management-marketing and project management areas respectively.

\section{- WORK EXPERIENCE}

Academic 12 years of teaching experience includes working with College of Management Studies, University of Petroleum and Energy Studies, Dehradun, ITM (Institute for Technology and Management), Warangal Andhra Pradesh and with International School of Busines \& Media, Nande, Pune.

Taught Subjects like Econometrics, Project management, Operations Management Quantitative Techniques Research Methodology at the University of Petroleum \& Energy Studies in the Post \& Under Graduate courses in the areas of Oil \& Gas, Power, Pipe line Engineering, Gas Engineering, Energy trading, Infrastructure, Aviation, Logistic \& Supply Chain, Port \& Shipping Management \& International Business.

Teaching Interest: Business Statistics, Operations Management, Project Management, Business Research Methods and Market Research.

Research Interest: Data Driven Models, Predictive Modelling, Simulation, Analytics and Benchmarking. 